\title{
Compatibility of Trichoderma viride and Trichoderma harzianum with Fungicides against Soil Borne Diseases of Tomato and Cabbage
}

\author{
H.M. Shashikumar ${ }^{1 *}$, Sumangala Koulagi ${ }^{1}$ and S.E. Navyashree ${ }^{2}$ \\ ${ }^{1}$ Department of Plant Pathology, K. R. C. C. H., Arabhavi-591218, Gokak, Karnataka, India \\ ${ }^{2}$ University of Horticultural Sciences, Bagalkot -587104, India \\ *Corresponding author
}

\section{A B S T R A C T}

\begin{tabular}{|c|c|}
\hline $\begin{array}{l}\text { Ke y w o r d s } \\
\text { Trichoderma viride, } \\
\text { Trichoderma } \\
\text { harzianum, } \\
\text { Fungicides }\end{array}$ & $\begin{array}{l}\text { A study was undertaken to evaluate the compatibility of commonly used fungicides at } \\
\text { recommended dosages with } T \text {. viride and } T \text {. harzianum being used as a biocontrol agents } \\
\text { against soil borne diseases of tomato and cabbage under in vitro and in vivo conditions. } \\
\text { Results indicated that among systemic fungicides, Azoxystrobin was found highly } \\
\text { compatible with } T \text {. viride and } T \text {. harzianum at all the three tested concentrations }(0.05 \text {, } \\
0.10 \text { and } 0.15 \% \text { ) followed by Metalaxyl. With respect to non-systemic fungicides, }\end{array}$ \\
\hline Article Info & $\begin{array}{l}\text { Mancozeb recorded least inhibitory effect on Trichoderma sp. Further compatible } \\
\text { combinations were evaluated in vivo to know the survival population of Trichoderma in }\end{array}$ \\
\hline $\begin{array}{l}\text { Accepted: } \\
\text { 15 March } 2019 \\
\text { Available Online: } \\
10 \text { April } 2019\end{array}$ & $\begin{array}{l}\text { soil media cropped with tomato and cabbage. Compatible combinations at their } \\
\text { recommended dosage can be recommended for integrated management of soil borne } \\
\text { pathogens of these crops. }\end{array}$ \\
\hline
\end{tabular}

\section{Introduction}

Biological control of soil borne plant pathogens by species of Trichoderma is a vital area of plant pathological research all over the world in these days (Mukhopadyay, 1987). Most of the soil borne diseases is not amenable for management through chemicals. Use of several antagonistic species of Trichoderma (T. viride, T. harzianum) against a range of economically important soil borne plant pathogens have been well documented (Cook and Baker, 1983). In recent years, the search of biological control agents for the management of dreaded soil borne diseases has been advocated widely. Since the biocontrol agents are applied either to seed or soil or both, there is every possibility of interaction and interference that would arise with the commonly used fungicides. The full expression of potential biocontrol is considered in terms of rhizosphere competence, suppression of pathogens, tolerance to pesticides, competitive saprophytic ability, adaptability to environment etc. Combined application of biocontrol agents with commonly used fungicides may result either in synergism / 
antagonism between these two. Various fungicides are recommended for the management of major soil borne pathogens. Looking for the broad spectrum performance of $T$. viride and $T$. harzianum against most of the soil borne fungi and foliar diseases, its compatibility with the other recommended chemical fungicides are found to be essential so that synergistic effect can be obtained for the management of diseases. Though few studies about the sensitivity of biocontrol agents with certain fungicides are available, studies with special reference to commercially available biocontrol agents, species of Trichoderma are meagre compatibility of living organisms with modern inputs in plant protection like fungicides is pre-requisite for disease management. Hence, there is need to test the compatibility studies of fungicides with $T$. viride and $T$. harzianum, their influence on rhizosphere mycoflora of various crops. Tomato and cabbage are very important crops grown in Karnataka and use of biocontrol agents as well as chemical fungicides are essential for managing disease of these crops especially soil borne and seed borne diseases. Therefore, it is very much essential to know the compatibility between these various bio agents and fungicides.

\section{Materials and Methods}

\section{Collection of test organism}

The culture of antagonistic microorganism Trichoderma harzianum was obtained from department of Plant Pathology, KRCCH, Arabhavi. Cultures of Trichoderma viride, Bacillus substilis, Lecaenicilium lecanii, Pseudomonas fluorescens, Metarrhizium anisopliae, Paecilomyces lilacinus were obtained from department of Plant Pathology, UAS Dharwad.

\section{Maintenance of culture}

The fungus was sub cultured on potato dextrose agar slants and allowed to grow at
$26 \pm 1^{\circ} \mathrm{C}$ for 7 days and such slants were preserved in a refrigerator at $4{ }^{0} \mathrm{C}$ and sub cultured once in 30 days.

Compatibility of Trichoderma sp. with fungicides under in vitro conditions

Efficacy of six fungicides was evaluated against the $T$. viride and $T$. harzianum by poisoned food technique as described by Dhingra and Sinclair (1995). Using poisoned food technique in PDA media, for each treatment, $60 \mathrm{ml}$ PDA was taken in $100 \mathrm{ml}$ conical flask and sterilized. To this medium specified quantity of the test chemical was added to get desired concentration at lukewarm temperature and mixed thoroughly by shaking the flasks. The poisoned medium was poured aseptically into sterilized petri plates and allowed to solidify. For each treatment, three replications were maintained. Mycelial discs (5 $\mathrm{mm}$ diameter) of the test isolates of $T$. viride and $T$. harzianum culture (one week old) were cut from periphery of colony with sterile cork borer and transferred into the centre of poisoned medium in each of the petri plate. Suitable controls were maintained by placing discs $(5 \mathrm{~mm})$ of isolates of Trichoderma sp. in petri plates containing untreated medium (i.e., without chemical). All the inoculated petri plates were incubated at $28 \pm 2^{\circ} \mathrm{C}$ in a BOD. The colony diameter of various isolates of Trichoderma sp. was measured in two directions and average was recorded in each treated petri plates when the colony growth in the control plate was full. Per cent inhibitions of mycelia growth of the fungus were calculated by using following formula (Vincent, 1927).

$$
\begin{aligned}
& \mathrm{PI}=\frac{\mathrm{C}-\mathrm{T}}{\mathrm{C}} \times 100 \\
& \mathrm{PI}=\text { Percentage inhibition } \\
& \mathrm{C}=\text { Radial growth of the Trichoderma in } \\
& \text { control plate }(\mathrm{cm}) \\
& \mathrm{T}=\text { Radial growth of the Trichoderma in } \\
& \text { treatments }(\mathrm{cm})
\end{aligned}
$$


Evaluation of compatible fungicides under in vivo condition

The combined effect of the Trichoderma sp. and the effective fungicides were tested in pot culture. Sterilized pot containing sterilized red soil and farm yard manure in the ratio of $2: 1$ were used in the study. Three replications for each treatment were tried. The compatible treatments were evaluated in pot culture experiment to know the population density of Trichoderma sp. Tomato and cabbage seedlings were raised in protrays, 30 days old seedling was transplanted into pots. At the time of transplanting, Trichoderma at the concentration of $5 \mathrm{~g} / \mathrm{kg}$ soil $\left(2 \times 10^{8} \mathrm{cfu} / \mathrm{g}\right)$ were treated with potting mixture. The compatible fungicides were applied to tomato and cabbage at 20 days after transplanting and again same treatments were taken up at 45 days after planting whereas other compatible bio agents were applied to soil at $5 \mathrm{~g} / \mathrm{kg}$ soil at the time of transplanting. Soil samples were collected from rhizosphere of treated tomato and cabbage crops for estimation of Trichoderma sp. population. Re isolation of Trichoderma sp. was done at 30 days and 60 days after transplanting (DAT). The population of Trichoderma sp. were estimated by dilution plate method using Trichoderma specific media (TSM) (Elad and Chet, 1983). Control was not applied with any of the fungicides.

Re isolation of Trichoderma sp. from tomato and cabbage rhizosphere

Collected rhizosphere soil samples were air dried for $4 \mathrm{hr}$ and used for the isolation of Trichoderma sp. by dilution plate technique (Elad and Chet, 1983). Serial dilution was done by pour plate method. One gram of the air dried soil was taken in $9 \mathrm{ml}$ of sterile distilled water and serially diluted. Serial dilution up to $10^{-4}$ was made and $1 \mathrm{ml}$ from each dilution was poured into Petri dishes and $20 \mathrm{ml}$ of TSM was added. The plates were incubated at $26 \pm 2^{\circ} \mathrm{C}$ for 7 days. After seven days colony farming units were recorded.

\section{Results and Discussion}

Soil borne plant pathogens are very difficult to control by using any single method of control. Therefore, Integrated Disease Management (IDM) is an acceptable approach in control of the diseases caused by various soil borne pathogens. As biological control has become one of the important components in IDM, it is inevitable that biocontrol agents are often applied along with fungicides either to plant or soil or both which may result in either synergism or antagonism between them. As most of the commonly used fungicides exert either positive, negative or neutral effects on biocontrol agents, the present study on compatibility of Trichoderma sp. with various fungicides commonly used in tomato and cabbage crops were evaluated under in vitro and in vivo condition. Results obtained in the investigation are discussed here under.

\section{Compatibility of Trichoderma sp. with fungicides}

Compatibility of Trichoderma sp. was evaluated against systemic and non-systemic fungicides. Among systemic fungicides Azoxystrobin was found highly compatible with $T$. harzianum and $T$. viride $(0.00 \%$ inhibition) at three tested concentration followed by Metalaxyl. Highest inhibition was recorded in Carbendazim. Compatibility of Trichoderma sp. with Azoxystrobin was also reported by Ranganathswamy et al., (2012). Similarly Sawant and Mukhopadyay (1990) observed that the radial growth of $T$. harzianum was not inhibited by Metalaxyl even upto $1000 \mathrm{ppm}$ concentration and noncompatibility of Trichoderma sp. with Carbendazim was also reported by Ramarethinam et al., (2001) and Bheemaraya et al., (2012). 
Table.1A List of fungicides

\begin{tabular}{|c|c|c|c|c|c|c|c|}
\hline Sl. & Common name & Trade & Chemical name & Formulation & \multicolumn{3}{|c|}{ Concentration (\%) } \\
\hline 1. & Azoxystrobin & Amistar & $\begin{array}{l}\text { Methyl(E)-2-\{2-[6-(2cyanophenoxy) } \\
\text { pyrimidin-4-yl } \\
\text { oxy]phenyl }\}-3-\text { methoxyacrylate }\end{array}$ & $23 \% \mathrm{SC}$ & 0.05 & 0.10 & 0.15 \\
\hline 2. & Metalaxyl & Mask & $\begin{array}{l}\text { Methyl N-(methoxyacetyl)-N-(2,6- } \\
\text { xylyl)-DL-alaninate }\end{array}$ & $35 \% \mathrm{WS}$ & 0.15 & 0.20 & 0.25 \\
\hline 3. & Carbendazim & Teja & methylbenzimidazol-2-ylcarbamate & $50 \% \mathrm{WP}$ & 0.05 & 0.10 & 0.15 \\
\hline 4. & Chlorothalonil & Kavach & 2,4,5,6- tetrachloroisophthalonitrile & $75 \% \mathrm{WP}$ & 0.15 & 0.20 & 0.25 \\
\hline 5. & $\begin{array}{l}\text { Copper } \\
\text { chloride }\end{array}$ & Blitox & Copper oxychloride & $50 \% \mathrm{WP}$ & 0.25 & 0.30 & 0.35 \\
\hline 6. & Mancozeb & $\begin{array}{l}\text { Dithane } \\
\text { M-45 }\end{array}$ & $\begin{array}{ll}\begin{array}{l}\text { Manganese } \\
\text { (dithiocarbamate) }\end{array} & \text { ethylenebis } \\
\text { (polymeric) }\end{array}$ & $75 \% \mathrm{WP}$ & 0.15 & 0.20 & 0.25 \\
\hline
\end{tabular}


Table.1B Compatibility of Trichoderma sp. with fungicides at different concentrations

\begin{tabular}{|c|c|c|c|c|c|c|}
\hline \multirow{2}{*}{$\begin{array}{l}\text { Sl. } \\
\text { No. }\end{array}$} & \multirow[t]{2}{*}{ Chemical name } & \multirow{2}{*}{$\begin{array}{l}\text { Concentr } \\
\text { ation }(\%)\end{array}$} & \multicolumn{2}{|c|}{ T. viride } & \multicolumn{2}{|c|}{ T. harzianum } \\
\hline & & & $\begin{array}{l}\text { Mycelial } \\
\text { growth (cm) }\end{array}$ & $\begin{array}{l}\text { Percent } \\
\text { inhibition (\%) }\end{array}$ & $\begin{array}{l}\text { Mycelial } \\
\text { growth (cm) }\end{array}$ & $\begin{array}{l}\text { Percent } \\
\text { inhibition (\%) }\end{array}$ \\
\hline \multirow[t]{3}{*}{1.} & \multirow[t]{3}{*}{$\begin{array}{l}\text { Metalaxyl } \\
(35 \% \mathrm{WS})\end{array}$} & 0.15 & 8.27 & $\begin{array}{c}8.15 \\
(16.56)^{*}\end{array}$ & 8.00 & $\begin{array}{c}11.11 \\
(19.45)\end{array}$ \\
\hline & & 0.20 & 7.87 & $\begin{array}{c}12.59 \\
(20.77)\end{array}$ & 7.83 & $\begin{array}{c}12.96 \\
(21.09)\end{array}$ \\
\hline & & 0.25 & 7.00 & $\begin{array}{c}22.22 \\
(28.12)\end{array}$ & 6.30 & $\begin{array}{c}30.00 \\
(33.20)\end{array}$ \\
\hline \multirow[t]{3}{*}{2.} & \multirow[t]{3}{*}{$\begin{array}{l}\text { Azoxystrobin } \\
(23 \% \text { SC) }\end{array}$} & 0.05 & 9.00 & $\begin{array}{c}0.00 \\
(0.33)\end{array}$ & 9.00 & $\begin{array}{c}0.00 \\
(0.33)\end{array}$ \\
\hline & & 0.10 & 9.00 & $\begin{array}{c}0.00 \\
(0.33)\end{array}$ & 9.00 & $\begin{array}{c}0.00 \\
(0.33)\end{array}$ \\
\hline & & 0.15 & 9.00 & $\begin{array}{c}0.00 \\
(0.33)\end{array}$ & 9.00 & $\begin{array}{c}0.00 \\
(0.33)\end{array}$ \\
\hline \multirow[t]{3}{*}{3.} & \multirow[t]{3}{*}{$\begin{array}{l}\text { Mancozeb } \\
\text { (75\% WP) }\end{array}$} & 0.15 & 8.90 & $\begin{array}{c}1.11 \\
(5.43)\end{array}$ & 8.87 & $\begin{array}{c}1.48 \\
(6.67)\end{array}$ \\
\hline & & 0.20 & 8.40 & $\begin{array}{c}6.67 \\
(14.94)\end{array}$ & 8.33 & $\begin{array}{c}7.41 \\
(15.77)\end{array}$ \\
\hline & & 0.25 & 8.33 & $\begin{array}{c}7.41 \\
(15.77)\end{array}$ & 8.23 & $\begin{array}{c}8.52 \\
(16.95)\end{array}$ \\
\hline \multirow[t]{3}{*}{4.} & \multirow{3}{*}{$\begin{array}{l}\text { Copper } \\
\text { Oxy Chloride } \\
(50 \% \text { WP })\end{array}$} & 0.25 & 3.63 & $\begin{array}{c}59.63 \\
(50.55)\end{array}$ & 3.50 & $\begin{array}{c}61.11 \\
(51.42)\end{array}$ \\
\hline & & 0.30 & 3.03 & $\begin{array}{c}66.30 \\
(54.51)\end{array}$ & 2.90 & $\begin{array}{c}67.78 \\
(55.41)\end{array}$ \\
\hline & & 0.35 & 2.27 & $\begin{array}{c}74.81 \\
(59.87)\end{array}$ & 2.17 & $\begin{array}{c}75.93 \\
(60.62)\end{array}$ \\
\hline \multirow[t]{3}{*}{5.} & \multirow[t]{3}{*}{$\begin{array}{l}\text { Carbendazim } \\
(50 \% \mathrm{WP})\end{array}$} & 0.05 & 0.73 & $\begin{array}{c}91.85 \\
(73.43)\end{array}$ & 0.70 & $\begin{array}{c}92.22 \\
(72.78)\end{array}$ \\
\hline & & 0.10 & 0.53 & $\begin{array}{c}94.07 \\
(75.93)\end{array}$ & 0.53 & $\begin{array}{c}94.07 \\
(75.93)\end{array}$ \\
\hline & & 0.15 & 0.50 & $\begin{array}{c}94.44 \\
(76.39)\end{array}$ & 0.50 & $\begin{array}{c}94.44 \\
(76.39)\end{array}$ \\
\hline \multirow[t]{3}{*}{6.} & \multirow[t]{3}{*}{$\begin{array}{l}\text { Chlorathalonil } \\
\text { (75\% WP) }\end{array}$} & 0.15 & 2.50 & $\begin{array}{c}72.22 \\
(58.19)\end{array}$ & 1.40 & $\begin{array}{c}84.44 \\
(66.77)\end{array}$ \\
\hline & & 0.20 & 2.23 & $\begin{array}{c}75.19 \\
(60.12)\end{array}$ & 1.13 & $\begin{array}{c}87.41 \\
(69.22)\end{array}$ \\
\hline & & 0.25 & 1.67 & $\begin{array}{c}81.48 \\
(64.51)\end{array}$ & 0.83 & $\begin{array}{c}90.74 \\
(72.29)\end{array}$ \\
\hline 7. & Control & - & 9.00 & -- & 9.00 & -- \\
\hline \multirow{2}{*}{\multicolumn{2}{|c|}{ S. Em \pm}} & & 0.12 & 1.58 & 0.13 & 1.59 \\
\hline & & & 0.36 & 4.72 & 0.38 & 4.77 \\
\hline
\end{tabular}

*Figures in the parentheses are arc sin transformed values 
Table.2 Evaluation of compatible fungicides with Trichoderma sp. in tomato crop under in vivo conditions

\begin{tabular}{|c|c|c|c|c|c|c|}
\hline \multirow[t]{2}{*}{$\begin{array}{l}\text { Sl. } \\
\text { No. }\end{array}$} & \multirow[t]{2}{*}{ Treatments } & \multirow[t]{2}{*}{$\begin{array}{c}\text { Concentration } \\
(\%)\end{array}$} & \multicolumn{2}{|c|}{$\begin{array}{l}\text { Population density of } T \text {. } \\
\text { viride (Cfu } \mathrm{g}^{-1} \text { soil) }\end{array}$} & \multicolumn{2}{|c|}{$\begin{array}{l}\text { Population density of } \\
\text { T. harzianum (Cfu } \mathrm{g}^{-1} \text { soil) }\end{array}$} \\
\hline & & & 30 DAT & 60 DAT & 30 DAT & 60 DAT \\
\hline \multirow[t]{3}{*}{1.} & \multirow{3}{*}{$\begin{array}{l}\text { Mancozeb } \\
(75 \% \text { WP) }\end{array}$} & 0.15 & 4.44 & 4.70 & 4.33 & 4.78 \\
\hline & & 0.20 & 4.22 & 4.52 & 4.22 & 4.55 \\
\hline & & 0.25 & 3.89 & 4.19 & 3.89 & 4.33 \\
\hline \multirow[t]{3}{*}{2.} & \multirow{3}{*}{$\begin{array}{l}\text { Azoxystrobi } \\
\text { n (23\% SC) }\end{array}$} & 0.05 & 4.78 & 4.93 & 4.33 & 5.00 \\
\hline & & 0.10 & 4.67 & 4.89 & 4.22 & 4.89 \\
\hline & & 0.15 & 4.00 & 4.33 & 3.89 & 4.78 \\
\hline \multirow[t]{3}{*}{3.} & \multirow{3}{*}{$\begin{array}{l}\text { Metalaxyl } \\
\text { (35\% WS) }\end{array}$} & 0.15 & 3.89 & 4.30 & 3.67 & 4.45 \\
\hline & & 0.20 & 3.67 & 4.00 & 3.56 & 4.22 \\
\hline & & 0.25 & 3.22 & 3.63 & 3.33 & 3.89 \\
\hline \multirow[t]{3}{*}{4.} & Control & - & 5.33 & 5.44 & 5.22 & 5.44 \\
\hline & & S. Em \pm & 0.24 & 0.20 & 0.28 & 0.27 \\
\hline & & CD@ 0 & 0.71 & 0.58 & 0.82 & 0.80 \\
\hline
\end{tabular}

Cfu - Colony forming unit

DAT - Days After Transplanting

Table.3 Evaluation of compatible fungicides with Trichoderma sp. in cabbage crop under in vivo conditions

\begin{tabular}{|c|c|c|c|c|c|c|}
\hline \multirow[t]{2}{*}{$\begin{array}{l}\text { Sl. } \\
\text { No. }\end{array}$} & \multirow[t]{2}{*}{ Treatments } & \multirow[t]{2}{*}{$\begin{array}{c}\text { Concentration } \\
(\%)\end{array}$} & \multicolumn{2}{|c|}{$\begin{array}{l}\text { Population density of } \\
\text { T. viride (Cfu } \mathrm{g}^{-1} \text { soil) }\end{array}$} & \multicolumn{2}{|c|}{$\begin{array}{l}\text { Population density of } \\
\text { T. harzianum (Cfu } \mathrm{g}^{-1} \text { soil) }\end{array}$} \\
\hline & & & 30 DAT & 60 DAT & 30 DAT & 60 DAT \\
\hline \multirow[t]{3}{*}{1.} & \multirow{3}{*}{$\begin{array}{l}\text { Mancozeb } \\
\text { (75\% WP) }\end{array}$} & 0.15 & 4.11 & 4.44 & 4.11 & 4.45 \\
\hline & & 0.20 & 3.78 & 4.22 & 3.89 & 4.33 \\
\hline & & 0.25 & 3.44 & 3.89 & 3.78 & 4.22 \\
\hline \multirow[t]{3}{*}{2.} & \multirow{3}{*}{$\begin{array}{l}\text { Azoxystrobin } \\
(23 \% \text { SC) }\end{array}$} & 0.05 & 4.22 & 4.78 & 4.33 & 4.89 \\
\hline & & 0.10 & 4.22 & 4.67 & 4.20 & 4.56 \\
\hline & & 0.15 & 3.56 & 4.00 & 3.68 & 4.44 \\
\hline \multirow[t]{3}{*}{3.} & \multirow{3}{*}{$\begin{array}{l}\text { Metalaxyl } \\
(35 \% \text { WS })\end{array}$} & 0.15 & 3.44 & 3.89 & 3.56 & 4.00 \\
\hline & & 0.20 & 3.33 & 3.67 & 3.40 & 3.89 \\
\hline & & 0.25 & 2.78 & 3.22 & 3.11 & 3.44 \\
\hline \multirow[t]{3}{*}{4.} & Control & & 5.11 & 5.33 & 5.22 & 5.33 \\
\hline & & S. Em \pm & 0.24 & 0.16 & 0.23 & 0.15 \\
\hline & & CD@5\% & 0.72 & 0.48 & 0.68 & 0.44 \\
\hline
\end{tabular}

$\mathrm{Cfu}$ - Colony forming unit

DAT - Days After Transplanting

In our study, non-systemic fungicide Mancozeb recorded least inhibitory effect on Trichoderma sp. (@0.25\% conc.). Similarly
Mancozeb recorded least inhibitory effect of radial growth of Trichoderma sp. which was reported by earlier scientists Malathi et al., 
(2002) and Nandeesha et al., (2013). Other non-systemic fungicides viz., Copper Oxy Chloride, Chlorothalonil were recorded incompatibility with Trichoderma sp. Incompatibility of these chemicals with Trichoderma bio agents were reported by Nishanth and Smita (2012).

In the present study, a progressive increase in per cent inhibition of radial growth of Trichoderma sp. was observed as the concentration of fungicides increased. These findings were agreement with the works of Durai (2004) and Srinivasulu et al., (2005) who also found good growth of Trichoderma isolates at low and medium concentrations of various fungicides.

Among two Trichoderma sp. tested for their compatibility against fungicides, $T$. viride showed more compatible reaction than $T$. harzianum at different concentrations. The differential response of Trichoderma sp. to various fungicides in the present study might be due to their inherent resistance to the fungicides and their ability to degrade these chemicals. Some strains of Trichoderma show compatibility with fungicides as they are tolerant of fungicides and can successfully use in IPM strategy (Dutta and Chatterjee, 2004). Besides having great antagonistic potential, Trichoderma has the capability of degrading xenobiotic compound and can survive in environment with remnant of fungicide molecules (Hetong et al., 2008). Results were displayed in Table 1.

Evaluation of compatible fungicides with Trichoderma sp. in tomato and cabbage crop under in vivo conditions

Different compatible combinations of fungicides were co-inoculated with Trichoderma sp. into the pot and Trichoderma population level were estimated at 30 and 60 days after inoculation. Among fungicides, significantly maximum population of Trichoderma sp. was recorded with Azoxystrobin. Bhai and Joseph (2010) were reported compatibility of $T$. harzianum with agrochemicals. In addition, they were found supportive to increase the population of $T$. harzianum under in vivo condition. Population level of Trichoderma increased from 30 to 60 days after Trichoderma application. The increase in the mycoflora may be due to increased senescence of leaves resulting in more saprophytic colonization. This observation was in agreement with Sudha Mall (1979) who reported that considering the age of the plant, the mycoflora of root zone increased with advancement of growth and after attainment of peak there was a progressive decline and again a flaring up of flora at senescent obviously because of saprophytic colonization. Results were presented in the Table 2 and 3.

Increased concentration of fungicides reduced the population level of Trichoderma observed in both tomato and cabbage crops. Similarly Agarwal et al., (2005) reported that as fungicides concentration increased, the growth has been decreased and minimum growth was observed with $1 \%$ concentration of bavistin as well as with dithane M-45. Both fungicides had deleterious effect on mycorrhizal spore number and percentage mycorrhizal root colonization. Similar effect may be operating under the present study condition also.

Summary and Conclusion are as follows:

$\checkmark \quad$ Among systemic fungicides, Azoxystrobin was found highly compatible with $T$. harzianum and $T$. viride at all the three tested concentrations (i.e., 0.05, 0.10 and $0.15 \%)$ followed by Metalaxyl. The highest inhibition was recorded in Carbendazim. 
$\checkmark \quad$ Among non-systemic fungicides, Mancozeb recorded least inhibitory effect on Trichoderma sp. and incompatibility was found with Copper Oxy Chloride and Chlorothalonil under in vitro conditions.

$\checkmark \quad$ Further compatible combinations were evaluated to know the survival population of Trichoderma in soil media cropped with tomato and cabbage crops. No significant difference in population of Trichoderma was noticed between treatments and control.

$\checkmark \quad$ The present study indicates that application of Trichoderma would be compatible with fungicides (viz., Mancozeb, Azoxystrobin and Metalaxyl) at recommended dosage and can be recommended for integrated management of soil borne pathogens of these crops.

\section{References}

Agarwal, A., Sharma, D., Prakash, V., Sharma, S. and Gupta, A., 2005, Effect of Bavistin and Dithan M-45 on the Mycorrhizae and Rhizosphere. Microbes of sunflower. 28 (42):75-88.

Bhai, R. S. and Joseph, T., 2010, Compatibility of Trichoderma harzianum (Rifai.) with fungicides, insecticides and fertilizers. Indian Phytopathol., 63(2): 145-148.

Bheemaraya Patil, M. B., Ramesh Vendan, K. T., Amaresh, Y. M. and Rao, K., 2012, Compatibility of Trichoderma spp. with commonly used fungicide, insecticide and plant extract. Indian J. Plant Protection, 40(2): (118-122).

Cook, R. I. and Baker, K. F., 1983, APS Books, St. Paul., MN, U.S.A:539.

Dhingra, O. D. and Sinclair, J. B., 1995, Basic plant pathology methods. $C B S$ Publications and Distribution, New Delhi, pp.335.

Durai, M., 2004, Management of charcoal rot of sesame (Sesamum indicum L.) incited by Macrophomina phaseolina (Tassi.) Goid. M. Sc. (Ag.) Thesis. Acharya N G Ranga Agric. Uni., Hyderabad.

Dutta, S. and Chatterjee, N. C., 2004, Raising of Carbendazim-tolerant mutants of Trichoderma and variations in their hydrolytic enzyme activity in relation to mycoparasitic action against Rhizopus stolonifer, J. of Plant Diseases Protection, 111(6): 557-565.

Elad, Y. and Chet, I., 1983, Improved selective media for isolation of Trichoderma spp., Fusarium spp. Phytoparasitica., 11: 55-58.

Hetong, Y., Ryder, M. and Wenghua, T., 2008, Toxicity of Fungicides and Selective Medium development for isolation and enumeration of Trichoderma spp. In: agricultural soils. International Subcommision on Trichoderma and Hypocrea Taxonomy, China 2008.

Malathi, P., Viswanathan, R., Padmanaban, P. and Sunder, A. R., 2002, Compatibility of bio control agents with fungicides against red rot of sugarcane. Sugar Tech., 4(3): 131-136.

Mukhopadyay, A. N., 1987, Biological control of soil borne plant pathogens by Trichoderma spp. Presidential address delivered at the $9^{\text {th }}$ Annual meeting of the Society of Mycology and Plant Pathology. Indian J. Mycol. Plant Pathol., 17: 1-10.

Nandeesha, B. S., Reddikumar, M. and Reddy, E. N. P., 2013, Evaluation of different fungicides and their compatibility with potential Trichoderma sp. for the management of Aspergillus niger, incitant of collar rot of groundnut. Asian J. of Biological Life Sci., 2 (1): 59-63.

Nishanth, P. and Smita, P., 2012, Efficacy of combination of systemic and nonsystemic fungicides against stem rot of 
rice. Bioscan, 7(2): 291-294.

Ramarethinam, S., Murugesan, N. V. and Marimuthu, S., 2001, Compatibility studies of fungicides with Trichoderma viride used in commercial formulation. Bio-Cure-F. Pestol., 25(5): 2-6.

Ranganathswamy, M., Patibanda, A. K., Chandrasekhar, G. S., Sandeep, D., Mallesh, S. B. and Kumar, H. B. H., 2012, Compatibility of Trichoderma isolates with selected fungicides in vitro. Int. J. of Plant Protection, 5 (1): 12-15.

Sawant, I. S. and Mukhopadyay, A. N., 1990, Integration of metalaxyl with Trichoderma harzianum for the control of Pythium damping-off in sugarbeet. Indian Phytopathol., 43: 535-541.

Srinivasulu, K., Kumar, B., Aruna, V., Prasadji and Rao, K., 2005, In vitro antagonism of three Trichoderma sp. against Sclerotium rolfsii Sacc., a collar-rot pathogen in elephant foot yam. J. of Biological Control, 19(2): 167-171.

Sudha Mall, 1979, Rhizosphere and rhizoplane microflora of three potato varieties. Indian Phytopathol., 32: 5154.

Vincent, J. M., 1927, Distortion of fungal hyphae in presence of certain inhibitors. Nature, 159: 850.

\section{How to cite this article:}

Shashikumar, H.M., Sumangala Koulagi and Navyashree, S.E. 2019. Compatibility of Trichoderma viride and Trichoderma harzianum with Fungicides against Soil Borne Diseases of Tomato and Cabbage. Int.J.Curr.Microbiol.App.Sci. 8(04): 1920-1928. doi: https://doi.org/10.20546/ijcmas.2019.804.225 